\title{
Amikor a bíró visszaél a függetlenségével ${ }^{1}$
}

\author{
Az önkényes/contra legem bírói döntések \\ alkotmánybirósági megitélésének evolúciója
}

\section{HÖRCHERNÉ MAROSI ILDIKÓ ${ }^{2}$ - KOVÁTS BEÁTA ${ }^{3}$}

Az Alaptörvény által bevezetett alkotmányjogi panasz, a bírói döntések alkotmányossági felülvizsgálatának lehetösége újradimenzionálta az Alkotmánybíróság és a bírói hatalmi ág viszonyát. Olyan új kérdéseket vetett fel, mint hogy vannak-e az Alkotmánybiróság tevékenységének igazságszolgáltatási elemei, a bírói igazságszolgáltatás belső kontrollmechanizmusának és az alkotmányossági felülvizsgálatnak az egymáshoz való viszonya, vagy éppen mi lehet az alkotmányossági felülvizsgálat helyes iránya és annak tartalma („eredmény-” vagy „jogértelmezéskontroll”).

E kérdések elemzésének keretéül az Alaptörvény XXVIII. cikk (1) bekezdésében elismert processzuális alapjog szolgál, amelynek tartalmát az alkotmánybírósági esetjog egy sor új elemmel gazdagította az elmúlt időszakban. A vizsgálat középpontjában tartalmi oldalról a contra legem, illetve az önkényes birói döntés mibenlétének kérdése áll.

Kulcsszavak: alkotmányjogi panasz, alkotmányossági felülvizsgálat, bírói igazságszolgáltatás belső kontrollmechanizmusa, contra legem bírói döntések

\section{When the Judge Misuses His Independence}

The Evolution of Constitutional Jurisdiction Concerning Arbitrary/Contra Legem Judicial Decisions

The constitutional complaint, introduced by the Fundamental Law, which is the option of constitutional review of judicial judgements, has repositioned the relationship of the Constitutional Court and the judicial branch. It has brought up new questions, like whether there are jurisdictional elements in the activity of the Constitutional Court, how do the internal control mechanism of judge-made jurisdiction and constitutional review relate to

20/2017. (VII. 18.) AB határozat, Indokolás [23].

21991 óta bíró. A magyar bírósági szervezet több szintjén polgári és közigazgatási ügyeket tárgyalt. A Kúria bírájaként 2016-ban választotta a magyar Országgyủlés az Alkotmánybíróság tagjává.

3 Az Alkotmánybíróság főtanácsadója. 
each other, or what can possibly be the right direction and content of constitutional review ("result" or "interpretation control").

To analyse these questions, the procedural fundamental right provides the framework, which is recognised in section (1) of Article XXVIII of the Fundamental Law. Its content has been made much more nuanced by a series of new elements introduced by the Constitutional Court recently. The question of the nature of contra legem and that of the arbitrary judicial decision stand in the centre of the investigation.

Keywords: constitutional complaint, constitutional review, internal control mechanism of judicial justice, contra legem judicial decisions

\section{Elözmények}

\subsection{A hagyományos jogorvoslati szerep Alkotmánybiróság általi elutasitása}

Az Alkotmánybíróságról szóló 2011. évi CLI. törvény 27. \$-a által bevezetett „valódi”, azaz a bírói döntésekkel szemben kezdeményezett alkotmányjogi panasz intézménye kihívás elé állította a korábban ilyen hatáskörrel nem rendelkező Alkotmánybíróságot, össze kellett ugyanis egyeztetni a bírósági ítélkezésben megnyilvánuló jogalkalmazási függetlenséget az Alkotmánybíróság által gyakorolt külső, alkotmányossági kontrollal.

Az esetjog konzekvensen alakult azt illetően, hogy a bírói döntések alaptörvénykonformitását vizsgáló Alkotmánybíróság tartózkodott attól, hogy szakjogi vagy kizárólag törvényértelmezési kérdésekben állást foglaljon. ${ }^{4}$ Ennek megfelelően visszatérő fordulat a visszautasító végzésekben a „szuperbírósági” és a hagyományos jogorvoslati szerep elutasítása általánosságban és kifejezetten az Alaptörvény XXVIII. cikk (1) bekezdésében rögzített tisztességes eljáráshoz való jog kapcsán is. A gyakorlattá szilárdult kiindulópont lényege szerint az Alkotmánybíróság „akkor vizsgálhatja érdemben a bírói jogértelmezés hibájára alapított alkotmányjogi panaszt, ha az eljárt bíróság az előtte folyamatban volt, valamely Alaptörvényben biztosított jog szempontjából releváns ügynek az alaptörvényi érintettségére tekintet nélkül járt el, vagy az általa kialakított jogértelmezés nem áll összhangban e jog alkotmányos tartalmával". ${ }^{5}$ Egyebekben a „jogszabályokat a bíróságok értelmezik, az Alkotmánybíróság csak az értelmezési tartomány alkotmányos kereteit jelölheti ki. Ez a jogkör azonban nem teremthet alapot arra, hogy minden olyan esetben beavatkozzon a bíróságok tevékenységébe, amikor olyan (állítólagos) jogszabálysértő jogalkalmazásra került sor, mely egyéb jogorvoslati eszközzel már nem orvosolható. [...] A bíró bármely ténybeli

4 Elsőként: 3003/2012. (VI. 21.) AB végzés, Indokolás [4]; legutóbb: 3296/2020. (VII. 17.) AB végzés, Indokolás [22]

5 3173/2015. (IX. 23.) AB határozat, Indokolás [53]. 
vagy jogi tévedése nem teszi automatikusan tisztességtelenné az egész eljárást, mivel az ilyen tévedések teljesen soha nem küszöbölhetők ki, azokat az igazságszolgáltatás ma ismert rendszere magában hordozza."

E megközelítés arra vezethető vissza, hogy a tisztességes eljáráshoz való jogot az Alkotmánybíróság nem az objektive helyes eredményt védő, hanem az eljárás során a birósági eljárással szemben támasztott eljárási garanciák rendszerét jelentö, úgynevezett processzuális alapjognak tekinti, amely a bírói döntés tartalmi kritikájára önmagában nem nyújt lehetőséget. ${ }^{7}$ Ezért amennyiben az alkotmányjogi panaszt pusztán a bizonyítási eljárást érintő és/vagy jogszabályalkalmazási kérdésekre alapítják - arra, hogy a bíróság rosszul döntött (nem megfelelően állapította meg a tényállást, a tényekből levont következtetése nem megalapozott) vagy döntése adott esetben contra legem (az alkalmazandó jog kiválasztása vagy értelmezése hibás) - a kérelmet érdemben nem bírálják el. ${ }^{8}$ Az ilyen jellegű sérelmek orvoslására nem az alkotmányjogi panasz, hanem a bírói igazságszolgáltatás keretei közötti belső kontrollmechanizmusok szolgálnak - ideértve végső fokon a Kúria rendkívüli jogorvoslati eljárásában gyakorolt kasszációs jogkörét is. A testület hatásköri önértelmezése szerint az alkotmányjogi panaszeljárás egyedüli célja a bírói döntés és az Alaptörvény összhangjának a megteremtése. Az Alkotmánybíróság valódi alkotmányjogi panaszeljárásban sem ismételt felülbírálati fórum. ${ }^{9}$

Az Alkotmánybíróság tehát hatáskörében eljárva nem bármely, az igazságszolgáltatás ma ismert rendszerének keretei között kiküszöbölhetetlen sérelmek, csupán az alkotmányossági tévedések korrekciójára vállalkozik. Emellett főszabályként meghagyja a bírónak úgy a törvényértelmezés szabadságát, mint a tévedés „lehetőségét”.

\subsection{Az indokolt bírói döntéshez való jog}

$\mathrm{Az}$ ismertetett restriktív megközelítéstől való minimális elmozdulást először a 7/2013. (III. 1.) AB határozat jelentett, amely a tisztességes eljáráshoz való jog Alaptörvényben nem nevesített, de abból levezethető részjogosítványaként nevesítette az indokolt bírói döntéshez való jogot.

Az a követelmény, hogy a bírónak a kérelembe foglalt, az ügy lényeges körülményeit érintő kérdéseket meg kell vizsgálnia, és vizsgálatának eredményéről az eljá-

6 Először: 3325/2012. (XI. 12.) AB végzés, Indokolás [14]-[15]. Kiemelés a szerzőktől.

7 Az Alkotmánybíróság többször megerősített döntése szerint a „fair trial olyan minőség, amelyet az eljárás egészének és körülményeinek figyelembevételével lehet csupán megítélni. Ezért egyes részletek hiánya ellenére éppúgy, mint az összes részletszabály betartása dacára lehet az eljárás »méltánytalan « vagy »igazságtalan«, avagy »nem tisztességes«" [6/1998. (III. 11.) AB határozat, ABH 1998, 91 95.].

8 Például: 3003/2012. (VI. 21.) AB végzés, Indokolás [4]; 3268/2012. (X. 4.) AB végzés, Indokolás [28]; 3352/2012. (XI. 12.) AB végzés, Indokolás [14]-[15]; 3392/2012. (XII. 30.) AB végzés, Indokolás [6]; 3017/2013. (I. 28.) AB végzés, Indokolás [3]; 3028/2014. (II. 17.) AB végzés, Indokolás [12]; 3037/2014. (III. 13.) AB határozat, Indokolás [30]; 3098/2014. (IV. 11.) AB végzés, Indokolás [28]; 3182/2016. (X. 4.) AB végzés, Indokolás [30]-[35].

9 Lásd például: 3107/2016. (V. 24.) AB végzés, Indokolás [35]. 
rási törvényeknek megfelelően számot kell adnia, a döntés tartalmi felülbírálatát továbbra is kizárta ugyan, de bizonyos szempontból a tartalmi jellegü vizsgálat felé mutatott. ${ }^{10} \mathrm{Az}$ indokolási kötelezettség négylépcsős tesztje értelmében ugyanis vizsgálni kell: 1. a jogvita természetét, 2 . az alkalmazandó eljárási törvény rendelkezéseit, 3. a felek által az adott ügyben előterjesztett kérelmeket és észrevételeket, valamint 4. az ügyben választ igénylő lényeges kérdéseket, ${ }^{11}$ ami már nem teszi lehetővé a szakjogi kérdéseknek a vizsgálatból való teljes körű kizárását. Még akkor is így van ez, ha az Alkotmánybíróság hangsúlyozta, hogy „[a] bíróságok indokolási kötelezettségéből nem következik a felek által felhozott minden észrevétel egyenként való megcáfolási kötelezettsége, különösen nem az indítványozó szubjektív elvárásait kielégítő mélységü érvrendszer bemutatása". ${ }^{12}$

\section{Az önkényes bírói döntés fogalmának genezise - az alkalmazandó jog időállapota és az indokolási kötelezettség}

Arra, hogy a jogszabályi rendelkezések - értelmezésen túlmutató - felülírása, kitágítása a bíróságok részéről alkotmányossági aggályt vethet fel, a bírói döntések alkotmányjogi panasz alapján történő vizsgálatára feljogosított Alkotmánybíróság viszonylag korán utalt. Kezdetben úgy tủnt, hogy a normatív alapját veszített, a törvényszövegtől eloldódott, adott esetben kirívó jogértelmezési hibában szenvedő bírói döntéssel összefüggésben elsősorban jogállamisági-jogbiztonsági [Alaptörvény B) cikk (1) bekezdés], ${ }^{13}$ illetve hatalommegosztási problémát [Alaptörvény C) cikk (1) bekezdés $]^{14}$ azonosít a testület. Ezzel viszont éppen az alkotmányjogi panasz alapján történő eljárást zárta volna ki, mivel ezek a rendelkezések - a B) cikk (1) bekezdése esetében a visszaható hatály tilalmát és a kellő felkészülési idő követelményét

10 A tartalmi jellegű vizsgálatra a Alkotmánybíróság döntéseiben is hivatkozott: „Az Alkotmánybíróság eddigi gyakorlatában a tisztességes eljáráshoz való jog érvényesülésének megítélését minden esetben tartalmi vizsgálathoz kötötte: mint ahogyan jelen ügyben is, elemezte az alapjog állított sérelmére vezető jogszabályi környezetet és bírói döntést, a szabályozás célját és a konkrét ügy tényállását, majd pedig - mérlegelés eredményeként - mindezekből vont le következtetéseket az adott esetre nézve megállapítható alapjogsérelemre nézve." \{3102/2017. (V. 8.) AB határozat, Indokolás [18]\}.

11 7/2013. (III. 1.) AB határozat, Indokolás [34].

12 30/2014. (IX. 30.) AB határozat, Indokolás [89]; 3183/2017. (VII. 14.) AB végzés, Indokolás [14].

13 „A zárt szabályok felülírása, "kitágítása" a bíróságok részéről ebben az ügyben már nem jogértelmezési, hanem contra legem jogalkalmazási - tulajdonképpen jogalkotási - tevékenységet jelentett volna, ami felvetette volna a bíróságok törvényeknek való alávetettsége elvének a sérelmét is. A jogállamiság elvéből, követelményéből az is következik, hogy a jogértelmezés nem válhat a jogalkalmazó szerv önkényes, szubjektív döntésének eszközévé. Ellenkező esetben sérülne a jogbiztonság követelménye, a jogalkalmazó szervek döntéseire vonatkozó kiszámíthatósági és előre láthatósági elvárás." \{3026/2015. (II. 9.) AB határozat, Indokolás [27]\}. Lásd hasonlóan: 3173/2015. (IX. 23.) AB határozat, Indokolás [52].

14 „[A]laptörvény-ellenessé azzal válhatna egy meghozott jogegységi határozat, ha a Kúria kilépne a jogegységesítő szerepéből és - a jogalkotót a jogalkotási folyamatból kihagyva - önállóan, a tételes jogi rendelkezéseket kibővítve, azokon túlhaladva, attól »eloldódva« jogot alkotna." $\{11 / 2015$. (V. 14.) AB határozat, Indokolás [30]\}. 
kivéve - nem tartalmaznak Alaptörvényben biztosított jogot, így rájuk alkotmányjogi panasz sem alapítható. ${ }^{15}$ Az Alaptörvény B) cikk (1) bekezdéséből akár levezethető lett volna egy harmadik Alaptörvényben biztosított jog is, de az Alkotmánybíróság nem ezt az utat választotta.

Jóllehet elvi szinten felvetődött korábban is, hogy a contra legem döntéseket akár az Alaptörvény XXVIII. cikk (1) bekezdése alapján is vizsgálni lehet, úgynevezett kirívó jogértelmezési hiba esetében, ${ }^{16}$ a fordulópontot a 20/2017. (VII. 18.) AB határozat jelentette, amely döntésében az Alkotmánybíróság markánsnak mondható alkotmányos határt szabott a törvénysértő, jogbeli tévedésben szenvedő, másképpen megfogalmazva: a törvényi alapjaitól eloldódott - az alkalmazandó jogot figyelmen kívül hagyó vagy az alkalmazandó jogszabályt helytelenül alkalmazó -, azaz önkényes bírói döntések számára.

E határozat végérvényesen eldöntötte, hogy az Alkotmánybíróság a bírói törvényértelmezésre mint aktusra (műveletre) nem anyagi jogi, szubsztantív jellegű minősítendő tényként tekint. Eszerint a bíró törvényhez kötött ítélkező tevékenysége elsődlegesen nem az Alaptörvény B) cikk (1) bekezdésében rögzített jogállamisággal, az annak részeként érvényesülő jogbiztonság elvével áll összefüggésben. Azt alapjogi oldalról, azon belül eljárási kérdésként ragadja meg, és ennek megfelelöen a bírói jogértelmezés és jogalkalmazás alkotmányosságát a tisztességes birósági eljáráshoz való processzuális jog függvényében vizsgálja.

A döntés alapjául szolgáló ügyben a vadászható állat által gépjárműben okozott kárért (úgynevezett vadkár) való felelősség kérdését elbíráló bíróság a veszélyes üzemek találkozására vonatkozó kárfelelősség szabályait alkalmazta annak ellenére, hogy az erre vonatkozó szabály a baleset idején már nem, az eredeti szabállyal harmonizáló törvénymódosítás pedig még nem volt hatályban. A bíróság úgy ítélte meg, hogy a már kihirdetett új rendelkezés az egyébként is irányadó bírói gyakorlatot emelte törvényi szintre. Az Alkotmánybíróság ezzel szemben megállapította, hogy e hivatkozás „nem egészen helytálló”, mert a baleset időpontjában azon jogszabályi rendelkezéseket, amelyekre a korábbi bírói gyakorlat épült, a jogalkotó már hatályon kívül helyezte, és a bírói gyakorlattal ellentétes tartalmú jogszabályi rendelkezések voltak hatályban, amely ténnyel a bíró tisztában volt. A levont következtetés értelmében - az adott ügyben - a vitatott másodfokú döntésnek nem volt törvényi alapja. Az „a bírói ítélet, amely alapos ok nélkül hagyja figyelmen kívül a hatályos jogot, önkényes, fogalmilag nem lehet tisztességes, és nem fér össze a jogállamiság alapelvével ${ }^{17}$ A testület öszszekapcsolta a jogszabályi alapot nélkülöző bírói ítéletet a bírói függetlenséggel is, amikor megállapította, hogy „a jogszabályokat be nem tartó bíróság lényegében viszszaél saját függetlenségével, amely adott esetben ezen keresztül a tisztességes bírósági eljáráshoz való jog sérelmét okozhatja".18

15 Vö. 3115/2016. (VI. 21.) AB határozat, Indokolás [27]-[33].

16 3173/2015. (IX. 23.) AB határozat, Indokolás [52]-[54].

17 20/2017. (VII. 18.) AB határozat, Indokolás [23].

18 20/2017. (VII. 17.) AB határozat, Indokolás [23]. 
A határozat ugyanakkor utalt arra, hogy a contra legem jogalkalmazás nem minden esetben emelkedik fel az alkotmányossági sérelem szintjére. A konkrét ügyben az alkalmazandó jog időállapotának a kiválasztása jelentette a contra legem elemet, a contra constitutionem jelleg pedig három körülmény együttes fennállása miatt volt megállapítható: 1. a bíróság „az indokolási kötelezettséget sértő módon nem indokolta meg, hogy az adott jogkérdésre irányadó, hatályos jogi normákat miért nem alkalmazta", 2. „a jogkérdésre nyilvánvalóan vonatkozó jogi normákat nem vette figyelembe”, és 3. döntését egy, már hatályon kívül helyezett jogi normához kapcsolódó joggyakorlatra alapította. ${ }^{19} \mathrm{~A}$ vizsgálat ebből következően kétlépcsős: elsődlegesen azt kell vizsgálni, hogy a támadott bírói döntés valóban contra legem-e, ezt követően pedig azt, hogy ez eléri-e az alaptörvény-ellenesség szintjét. A contra legem és contra constitutionem döntések alapvetően az indokolt birói döntés követelményének figyelembevételével, a jogalkalmazói önkény fennállása alapján különíthetők el, tehát a puszta jogértelmezési hiba, tévedés - még ha egyértelmü, esetleg kirívó is - nem releváns. ${ }^{20}$

Annak kifejezett kimondására nem került sor, hogy a tartalmilag hibás bírói konklúzió miatt interveniált volna az Alkotmánybíróság, formálisan az indokolási kötelezettség megsértését és ezzel összefüggésben a jogalkalmazás önkényességét rótta fel a bíróságnak. Ezzel együtt a döntésnek az alkalmazandó jog időállapota és ehhez kapcsolódó értelmezése tekintetében az alapügy kimenetelére kiható módon történő felülbírálata kétségkívül felülírta a tisztességes eljáráshoz való jog addigi gyakorlatát. Belátható, hogy valójában - hivatkozása ellenére - nem az indokolt bírói döntéshez való jog gyakorlatát fejlesztette tovább az Alkotmánybíróság, hanem terra incognitán járt, és a 7/2013. (III. 1.) AB határozat által bevezetett teszttől elszakadva - az Alaptörvény R) cikk (2) bekezdése és a 28. cikke jogértelmezési szabályának közvetítésével - megkezdte egy, a contra legem bírói döntések vizsgálhatóságára és ezen belül az önkényes jogalkalmazás tilalmára vonatkozó új teszt kidolgozását, amely a bírói döntés tartalmi kritikájára is módot nyújtva egyértelmű elmozdulást jelentett a tisztességes eljáráshoz való jog processzuális jellegének felfogásától.

A 20/2017. (VII. 17.) AB határozat mindenképpen hiánypótló jellegü, mivel a korábbiakban nem létezett egyértelmű külső kontroll a jogszabályi alapot nélkülöző, a jogon belül nem igazolható, másképpen fogalmazva: a nem „szabályvezérelt [bírói] döntésekkel"21 szemben. A határozat erénye továbbá, hogy a contra constitutionem döntés differentia specificájaként nem a jogértelmezés hibájának kirívó jellegét jelöl-

19 20/2017. (VII. 18.) AB határozat, Indokolás [29].

20 Később a 3128/2019. (VI. 5.) AB határozat is erre utalt, amikor deklaráltan a vizsgálat első lépéseként tekintett a döntés contra legem jellegének a mérlegelésére: az „alaptörvény-ellenesség megállapítása során mindenekelőtt abban a kérdésben kellett döntenie az Alkotmánybíróságnak, hogy az indítványozói állításoknak megfelelően valóban contra legem jogalkalmazás történt-e" (Indokolás [29]).

21 Fröhlich Johanna: Az Alkotmánybíróság és a Kúria alkotmányértelmezése: az Alaptörvény R) és 28. cikkei. In Gábor Zsolt (szerk.): Az Alaptörvény érvényesülése a bírói gyakorlatban. Budapest, HVG-ORAC, 2019. 355. 
te meg, megerősítve, hogy önmagában a birói tévedés (vagy annak nyilvánvalósága, esetleg súlyossága) nem okoz alaptörvény-ellenességet.

A határozat kritikájaként értékelhető azonban egyrészt, hogy a konkrét ügyben akár a fennálló gyakorlat megváltoztatása nélkül is lehetőség lett volna az ügy eldöntésére: megfelelő indokolással - és az alapjogi jogvédelem oldaláról is védhető módon - a kérdéskör kezelhető lett volna a jogállamiság/jogbiztonság oldaláról, a B) cikk (1) bekezdésének alapján. Az Alaptörvény B) cikk (1) bekezdésének jogállamisági követelménye a gyakorlat szerint a visszaható hatályú jogalkotás mellett a visszaható hatályú jogalkalmazást is tiltja. ${ }^{22}$ Mivel alapvetően egy, még nem hatályos jogszabályi elöírás alkalmazása - az alkalmazandó jog időállapotának a kiválasztása - körül forgott a vita, a B) cikk (1) bekezdésének a sérelme is aggálytanul megállapítható lett volna.

Másrészt nem egyértelmű, hogy miért volt szükség a XXVIII. cikk (1) bekezdésén belül kifejezetten az indokolt bírói döntéshez való jog körében kezelni az ügyet akkor, amikor a 7/2013. (III. 1.) AB határozat tesztjének alkalmazására nyilvánvalóan nem volt lehetőség vagy szükség, hiszen a döntés kifejezetten tartalmazott indokolást az alkalmazandó jog tekintetében, csak azt az Alkotmánybíróság contra legemnek, sőt önkényesnek tartotta.

Harmadrészt, ha el is fogadjuk azt az alaptételt, hogy a jogértelmezés nem válhat a jogalkalmazó szerv önkényes, szubjektív döntésének eszközévé - függetlenül attól, hogy ezt jogállami vagy a tisztességes eljáráshoz való jogra visszavezethető követelménynek tekintjük -, a határozat hiányossága, hogy a döntés hordereje és új gyakorlatot megalapozó jellege ellenére nem adott egyértelmű választ a jogalkalmazói önkény mibenlétének a kérdésére. Érezhető az a törekvés, hogy a testület értelmezésében az önkény fogalmát valamilyen módon a jogalkalmazói (jogértelmezési) kötelezettség szándékos megszegéséhez kell kapcsolni, és nem pusztán a jogalkalmazás eredménye alapján kell az önkényességet megítélni. De kétséges maradt az, hogy alkotmányossági oldalról mi a felismerhető kritériumon alapuló különbség a bírói tévedés - amelynek lehetőségét az „igazságszolgáltatás ma ismert rendszere magában hordozza" - és az alkotmányosan megengedhetetlen bírói önkény között.

\section{A jogszabályi célhoz kötött jogértelmezési alapelv (Alaptörvény 28. cikk) figyelmen kívül hagyása}

A 23/2018. (XII. 28.) AB határozat („MNB-ügy”) már nem az alkalmazandó jog időállapotának oldaláról, hanem a jogszabály-értelmezés tekintetében adott támpontot az önkényesség értelmezéséhez.

22 Lásd először elvi jelleggel: 3051/2016. (III. 22.) AB határozat, Indokolás [16]. Az elv gyakorlati alkalmazására példa a 3221/2019. (X. 11.) AB határozat, amely kifejezetten az Alaptörvény B) cikk (1) bekezdésének a sérelmét állapította meg hasonló ügyben, tehát amikor a bíróság egy, még nem hatályos jogszabály alkalmazásával döntött (Indokolás [24]). Hasonlóan lásd: 3136/2020. (V. 15.) $\mathrm{AB}$ határozat. 
A határozat szerint az Alaptörvény 28. cikke és XXVIII. cikk (1) bekezdése "természetes fogalmi egységet alkotnak”, és a „jogértelmezés Alaptörvényben rögzített elveinek betartása minden kétséget kizáróan részét képezi a tisztességes bírósági eljárásban megvalósuló jogértelmezéssel szemben állított minimális alkotmányos követelményeknek”. ${ }^{23}$ Ebből következően az Alaptörvény 28. cikkében foglalt jogértelmezési szabályok - a konkrét ügyben a jogszabály céljának - kifejezett figyelmen kívül hagyása önkényesség megállapítására vezethet. A jogszabályi célhoz kötött jogértelmezési alapelv figyelembevételének kötelezettsége azonban nem abszolút, mert az Alaptörvény 28. cikke „nem zárja ki, hogy a jogszabály tartalmának megállapításakor a bíróság egyéb szempontokra is figyelemmel legyen, és hogy ezek mérlegelése során, indokolt esetben, a jogszabály eredeti céljával ellentétes következtetésre jusson. Az a bírósági mérlegelés azonban, amely a jogszabály céljának vizsgálatát teljes mértékben és kifejezetten kizárja, már alaptörvény-ellenesnek minősül." ${ }^{24}$ A megsemmisítés indoka ebben az ügyben az volt, hogy a bíróság a kiadmányozás fogalmának értelmezésekor az alkalmazandó jogszabályi előírás szövegét egyértelmünek tekintve nem látott lehetőséget az Alaptörvény 28. cikkében írtak alkalmazására. A döntés elsősorban emiatt a kifejezett beismerés - az Alkotmánybíróság értelmezésében: szándékos mellözés - miatt volt önkényes (contra constitutionem).

Bár a döntés tartalmilag mintegy továbbfejlesztette a 20/2017. (VII. 18.) AB határozattal megalapozott gyakorlatot, itt már - helyesen - még említés szintjén sem került szóba az indokolt bírói döntéshez való jog. Az Alkotmánybíróság nem azt rótta fel a bíróságnak, hogy nem indokolta meg a döntését, hanem hogy kilépett abból a jogértelmezési keretböl, amelyet számára az Alaptörvény elöírt: figyelemmel az Alaptörvény 28. cikkében foglaltakra, a bírói jogértelmezés szerves részét kell hogy képezze az alkalmazandó jog kiválasztása mellett az alkalmazandó jog autentikus forrásból - 2018. január 1-jétől kezdődően az Alaptörvény értelmében egyebek mellett a miniszteri indokolásból - táplálkozó céljának vizsgálata. Ez az elvárás a bírói jogértelmezéssel szembeni minimális alkotmányossági követelménnyé vált.

Ez közvetve igazolja, hogy a jogalkalmazói önkény esete valójában eredetileg sem az indokolt bírói döntés mint a tisztességes eljáráshoz való jog részjogosítványa közvetítésével, hanem közvetlenül kapcsolódott az Alaptörvény XXVIII. cikk (1) bekezdéséhez. ${ }^{25}$

A gyakorlat formálása közbeni útkeresésre utal, hogy e döntésében az Alkotmánybíróság nem alkalmazta, vagy ha tetszik, megfordította/összeolvasztotta a 20/2017. (VII. 18.) AB határozat kétlépcsős tesztjét: a támadott bírósági döntés

23 23/2018. (XII. 28.) AB határozat, Indokolás [26]. A szövegrész szerzői kiemelés.

24 23/2018. (XII. 28.) AB határozat, Indokolás [30]. A szövegrész szerzői kiemelés.

25 Ettől függetlenül az indokolási kötelezettségre hivatkozás sem tűnt el a gyakorlatból, a 20/2017. (VII. 18.) AB határozat előtti gyakorlatra emlékeztető módon általában az érdemi vizsgálat akadályaként jelenik meg az az érv, hogy a bíróság „a támadott döntését részletesen megindokolta, kiemelve, hogy melyek voltak az adott jogkérdésre irányadó normák, és azokat miért az adott értelmezés mellett alkalmazta", és a bírói jogértelmezés kirívó - alapjogi relevanciát elérő - hibája nem azonosítható \{3164/2019. (VII. 10.) AB határozat, Indokolás [38]-[39]\}. 
az Alaptörvény 28. cikkének szándékos figyelmen kívül hagyása miatt volt önkényes, és kvázi az emiatt előállt hibás jogszabály-értelmezés okán vált contra legemmé. ${ }^{26}$

A határozat a 20/2017. (VII. 18.) AB határozattal szemben már szemernyi kétséget sem hagyott afelől, hogy melyik az egyedül helyesnek - alkotmányosnak - tekintett jogszabály-értelmezés. ${ }^{27} \mathrm{Ez}$ az alapügy tartalmi felülbírálata irányába történő hangsúlyos elmozdulást jelentett. Emellett arra enged következtetni, hogy a bírói mérlegelés detektált tartalmi hibája volt a megsemmisítés valódi indoka, ami az alkotmányossági és a törvényességi vizsgálat közötti alapvető különbség elmosódásának veszélyét hordozza, és egyúttal a tisztességes eljáráshoz való jog processzuális jellegének végleges feladását vetíti elóre. Amennyiben az Alkotmánybíróság a bírói jogértelmezést nemcsak akkor vizsgálja, ha a jogértelmezésnek van alapjogi (Alaptörvényben biztosított jogi) vonatkozása, hanem a tisztességes eljáráshoz való jog önmagában is lehetőséget ad a bírói döntés irányának felülvizsgálatára, ez végső soron a helyes, jogszabályszerü (igazságos?) jogalkalmazáshoz való jog elismeréséhez vezethet.

\section{Kirívó jogalkalmazási hiba}

\subsection{Hatályon kívül helyezett jogegységi határozat bevonása az alkalmazandó jog értelmezésébe}

A 3088/2019. (IV. 26.) AB határozat esetében az Alkotmánybíróságnak a tisztességes eljáráshoz való joggal összefüggésben egy, már hatályon kívül helyezett jogegységi határozat alkalmazását kellett megvizsgálnia. Hasonlóan tehát a 20/2017. (VII. 18.) $\mathrm{AB}$ határozathoz, az alkalmazandó jog időállapota állt az ügy fókuszában. Konklúziója szerint a korábban hatályos jogegységi határozatban kifejtett érvek figyelembevétele nem tekinthetö önkényes jogértelmezésnek, mert a hatályon kívül helyezés indoka a jogszabályi alap megszủnése volt, nem pedig az, hogy érdemben változott volna a joggyakorlat megítélése.

A 20/2017. (VII. 18.) AB határozat esetében - ha formálisan is - az indokolt bírói döntés sérelme teremtette meg a kapcsolatot a tisztességes eljáráshoz való joggal, a 23/2018. (XII. 28.) AB határozat esetében pedig az Alaptörvény 28. cikkébe foglalt jogértelmezési szabály figyelmen kívül hagyása. A hivatkozott határozat jelentősége viszont abban áll, hogy ebben az ügyben az Alkotmánybíróság először utalt az önkényes jogértelmezés tilalmára mint a tisztességes bírósági eljárásból közvetlenül

26 Hasonló összemosódás figyelhető meg a 3354/2020. (X. 14.) AB határozat, Indokolás [26]-[27]-ben is. A contra constitutionem jelleg azonosítását nehezíti továbbá, hogy egy későbbi döntés szerint viszont „[a] nem kellő pontossággal megfogalmazott jogszabályi rendelkezésen alapuló, a jogszabály szövegéhez képest nem contra legem jogértelmezés nem róható a jogalkalmazók terhére és nem minősíthető utóbb sem jogellenesnek" \{4/2020. (I. 29.) AB határozat, Indokolás [31]\}.

27 „Ezen megfontolások figyelembe vételével az Alaptörvény 28. cikkében foglalt, észszerủ és gazdaságos célra vonatkozó jogszabály-értelmezési kötelezettségeknek az MNB tv. 13. \$ (11) bekezdésében foglalt kiadmányozás fogalmának azon értelmezése felel meg, amely lehetővé teszi a PST érintett hatósági döntései meghozatalának delegálását." \{23/2018. (XII. 28.) AB határozat, Indokolás [31]\}. 
fakadó, önállóan vizsgálható követelményre. ${ }^{28} \mathrm{~A}$ mérlegelés lényegében közvetlenül arra irányult, hogy a jogalkalmazás ebben a formában megalapozott (helyes) vagy önkényes (helytelen) volt-e.

\subsection{Az alkalmazandó jog kiválasztásának problematikája}

A 24/2020. (X. 15.) AB határozat akként szintetizálta az önkényes bírói döntés problematikáját, hogy „[a] bírói jogértelmezés kirívó - alapjogi relevanciát elérő - hibája merül fel akkor, ha a bíróság a tisztességes bírósági eljáráshoz való jog mint eljárásjogi jellegű alapjog egy aspektusát, az indokolási kötelezettséget sértő módon nem indokolja meg, hogy az adott jogkérdésre irányadó, hatályos jogi normákat miért nem alkalmazza”. Az alaptörvény-ellenességet pedig azzal okozta a bíróság, hogy nem vette figyelembe az Alkotmánybíróság által feltárt jogszabályi rendelkezéseket, „és nem is indokolta azt, hogy az indítványozó ügyében a konkrét jogkérdésre irányadó, hatályos jogi normákat miért nem alkalmazta, jóllehet a mellőzött jogi normák [...] a korábban megállapított ellátás összege tekintetében az alkotmányos elvárásoknak megfelelő indok nélküli csökkentés akadályát képezik”.29

Nem lebecsülhető e megfogalmazás jelentősége a formálódó gyakorlat szempontjából.

Az alapügy tartalmi felülvizsgálatára irányuló utalást nem tekinthetjük újdonságnak, a 23/2018. (XII. 28.) AB határozat is megfogalmazott a konkrét ügy megoldására vonatkozó iránymutatást. Ezzel szemben a bírói jogértelmezés hibájára - a jogalkalmazói tévedésre - történő egyértelmủ utalás olyan novum, amely aggályos módon eloldja a vizsgálatot az önkényesség eddig megkerülhetetlennek tekintett kritériumától, és attól a fentebb idézett alapvetéstől, hogy „[a] bíró bármely ténybeli vagy jogi tévedése nem teszi automatikusan tisztességtelenné az egész eljárást, mivel az ilyen tévedések teljesen soha nem küszöbölhetők ki, azokat az igazságszolgáltatás ma ismert rendszere magában hordozza" ${ }^{30}$ Eddig, ha az Alkotmánybíróság nem tudott azonosítani önkényességet - a jogalkalmazói (jogértelmezési) kötelezettség szándékos, a bírósági döntés indokolásából kimutatható megszegését -, az esetleges jogalkalmazói tévedések korrekcióját nem végezte el a tisztességes bírósági eljáráshoz való jog sérelmére alapított panasz alapján. E gyakorlat esetleges megváltozásának rendkívüli jelentősége lehet.

A határozat másik újítása, hogy kifejezetten az alkalmazandó jog megválasztásával összefüggésben bírálta felül a bíróságot (egy konkrét elöírás alkalmazásának a hiányát problematizálta), ami messze túlmutat az alkalmazandó jog idóállapotával vagy értelmezésével kapcsolatos, eddig felmerült kérdéseken, és a korábban elutasított, hagyományos jogorvoslati szerepkör felé mutat.

28 3088/2019. (IV. 26.) AB határozat, Indokolás [26]-[28].

29 24/2020. (X. 15.) AB határozat, Indokolás [29], [34].

30 Először: 3325/2012. (XI. 12.) AB végzés, Indokolás [14]-[15]. 


\subsection{Józan ész mint jogértelmezési alapelv figyelmen kívül hagyása}

A jogalkalmazói tévedés vizsgálhatóságára vonatkozó irányváltást megerősítette a 3002/2021. (I. 14.) AB határozat is, amely szerint "fogalmilag nem lehet tisztességes az a bírósági eljárás, amely a józan ész követelményét figyelmen kívül hagyja. [...] Ellenkező esetben a bírósági jogalkalmazás pusztán automatizmussá válik, ami a bírósági eljárás tisztességtelenségét okozza." ${ }^{31}$ Az indítványozó tehát önmagában az alkalmazandó jogszabály értelmezésének a helyességét vitatta, és az Alkotmánybíróság - eltávolodva alapjogvédelmi szerepkörétől, új tartalommal töltve meg a tisztességes eljáráshoz való jogot és annak viszonyát a 28. cikkel - lényegében perorvoslati fórumként felülbírálta a támadott és jogalkalmazási szempontból hibásnak minősített bírói döntést. A határozat kizárólag a jogalkalmazás eredménye, egyértelműsége alapján állapította meg a tisztességes eljárás sérelmét, az önkényesség - mint a jogalkalmazói (jogértelmezési) kötelezettség szándékos megszegése nem volt része a mérlegelésnek.

A bírói jogértelmezés komplex intellektuális tevékenység, amelynek egyik alkotmányos mércéje minden bizonnyal a „józan ész” kell hogy legyen. Ugyanakkor egyedüli mérceként alkalmazva az igazság objektivitásának látszatát kelti. Azaz olyannyira szubjektív, hogy bizonyosan nem alkalmas a contra legem ügyek közül a contra constitutionem esetek azonosítására.

A testület többségi döntésének az a lényege, hogy a bíróság jogi tévedése, hibája - például az alkalmazandó jog helytelen megválasztása a 24/2020. (X. 15.) AB határozat esetében, vagy a józan ésszel össze nem férő, egyértelmű jogértelmezési hiba a 3002/2021. (I. 14.) AB határozat alapjául szolgáló ügyben - önmagában, kifejezett jogalkalmazói önkény azonosítása nélkül megvalósítja a tisztességes eljáráshoz való jog sérelmét. Ez viszont annak a veszélyével járhat, hogy végső soron minden jogalkalmazói jogsértés alapjogsértésként is manifesztálódhat. Ez az irány pedig azt jelentheti, hogy az Alkotmánybíróság - hatáskörét túllépve - hagyományos jogorvoslati, felülbírálati fórummá válik. ${ }^{32}$

\section{Konklúzió}

Összességében ismételten célszerủ rámutatni arra, hogy az Alkotmánybíróság alapjogi jogsértésnek tekinti azt, ha a bíró figyelmen kívül hagyja a perben alkalmazandó jogot vagy annak helyes értelmezését. Ez a mulasztás bizonyos esetekben „felér” az Alaptörvény szintjéig. Különösen ekként kezeli a testület azt a helyzetet, amikor a bíróság ítéletének indokolásából nem olvashatók ki alkotmányos megfontolások. Sőt, éppen ellenkezőleg, abból akár az Alaptörvény vagy Alaptörvényben rögzített értelmezési követelmény szándékos negligálása is lehetséges következtetésnek tünik.

31 3002/2021. (I. 14.) AB határozat, Indokolás [52]. A szövegrész szerzői kiemelés.

32 Vesd össze: Hörcherné Marosi Ildikó alkotmánybírónak a 3002/2021. (I. 14.) AB határozathoz füzött párhuzamos indokolása (Indokolás [76]-[80]). 
A testület tehát „alapjogiasította” az önkényes bírói döntések megítélését, amikor a kérdéskört a XXVIII. cikk (1) bekezdésének keretei között tartja. Ez a helyzet tovább gazdagította az amúgy lassan az Alkotmány 2 . $\mathbb{S}(1)$ bekezdéséhez (jogállamisági kla-

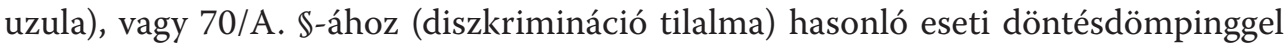
körülírt alaptörvényi rendelkezés tartalmát.

A XXVIII. cikk (1) bekezdésének „használata” a vonatkozó alapjogi dogmatika alkalmazását veti fel. Ebben az összefüggésben - figyelemmel a fentiekben hivatkozott határozatokra is - az a következtetés adódik, hogy ha egy bírói döntés „önkényes", akkor a bírói eljárás egészében, generálisan válik alaptörvény-ellenessé. Azonban ahhoz, hogy megállapítható legyen a bíró alkalmazott jogban való tévedése, az Alkotmánybíróságnak magának is vizsgálnia kell az ügyet, és - bírói talárba bújva - meg kell határoznia a perben alkalmazandó jogot, annak tartalmát, értelemszerủen a megfelelő idóállapottal együtt. A jog „megtalálása” és a megsemmisítő döntés meghozatala - figyelemmel az alkotmánybírósági egyedi határozatok erga omnes hatályára is - lényegileg egyet jelent a (peres) ügy megoldásával. A végső szót, az „igazságot” ma már nem a bíróság, hanem az Alkotmánybíróság mondja ki. Ahogy azt is az Alkotmánybíróság által kimunkált és alkalmazott teszt alapozza meg, hogy mely ügyek „érnek fel” az alkotmányellenesség szintjére, azaz a bíró melyik jogbeli tévedése lesz az, amely egyben contra constitutionem értelmezésnek is tekintendő. Mindazonáltal főszabályként ma is igaz az, hogy „[a] »jogot« végül is a bíróságok saját értelmezésük szerint állapítják meg”.33

Nem kétséges az, hogy az Alaptörvény XXVIII. cikk (1) bekezdéséhez füzött, fejlödő joggyakorlat, annak evolúciója alapvető hatást gyakorol a bírói jogértelmezés elvi megközelítésére és főként annak gyakorlati kérdéseire. De tágabb értelemben vizsgálatra érdemes módon értelmezi újra a bírósági eljárásokban alkalmazott jogorvoslati jogok tartalmát. Meddig terjed a bíróság, konkrétan a Kúria törvényességi felülvizsgálata, és mikortól veszi kezdetét az Alkotmánybíróság alkotmányossági kontrollja, mi a két kontroll tartalma és azok lehetséges keretei?

Összességében a legfontosabb kérdés azonban a bíróságok (bírói hatalmi ág) és az Alkotmánybíróság Alaptörvényben rögzített viszonyának keretei és tartalma: változott-e ez a viszony 2012. január 1-jétől, és ha igen, mennyiben?

\section{Irodalomjegyzék}

Fröhlich Johanna: Az Alkotmánybíróság és a Kúria alkotmányértelmezése: az Alaptörvény R) és 28. cikkei. In Gábor Zsolt (szerk.): Az Alaptörvény érvényesülése a bírói gyakorlatban. Budapest, HVG-ORAC, 2019. 342-364.

33 Lásd legutóbb: 3309/2020. (VII. 24.) AB határozat, Indokolás [20]. 


\section{Hivatkozott alkotmánybírósági határozatok}

6/1998. (III. 11.) AB határozat 3003/2012. (VI. 21.) AB végzés 3268/2012. (X. 4.) AB végzés $3325 / 2012$. (XI. 12.) AB végzés 3392/2012. (XII. 30.) AB végzés 7/2013. (III. 1.) AB határozat 3028/2014. (II. 17.) AB végzés 3037/2014. (III. 13.) AB határozat 3098/2014. (IV. 11.) AB végzés 30/2014. (IX. 30.) AB határozat 3026/2015. (II. 9.) AB határozat 11/2015. (V. 14.) AB határozat 3173/2015. (IX. 23.) AB határozat 3173/2015. (IX. 23.) AB határozat 3051/2016. (III. 22.) AB határozat 3107/2016. (V. 24.) AB végzés 3115/2016. (VI. 21.) AB határozat 3182/2016. (X. 4.) AB végzés 20/2017. (VII. 18.) AB határozat 3183/2017. (VII. 14.) AB végzés 20/2017. (VII. 18.) AB határozat 23/2018. (XII. 28.) AB határozat 3088/2019. (IV. 26.) AB határozat 3128/2019. (VI. 5.) AB határozat 3164/2019. (VII. 10.) AB határozat 3221/2019. (X. 11.) AB határozat 4/2020. (I. 29.) AB határozat 3136/2020. (V. 15.) AB határozat 3296/2020. (VII. 17.) AB végzés 3309/2020. (VII. 24.) AB határozat 3354/2020. (X. 14.) AB határozat 24/2020. (X. 15.) AB határozat 3002/2021. (I. 14.) AB határozat 